\title{
A Study on the Optimization of English Teaching in Higher Vocational Colleges under the "Internet+" Environment
}

\author{
Shanshan Ju \\ Jiangxi Technical College of Manufacturing 330095,China
}

Keywords: “Internet+”, Higher Vocational English teaching, optimization.

\begin{abstract}
The "Internet+" has greatly changed our traditional way of living and working, as well as teaching. Under the "Internet+" environment, Higher Vocational English teaching should make full use of Internet technology to enrich contents, innovate modes and improve teaching effects. Firstly, this paper analyzes the influence of "Internet+" on English teaching in Higher Vocational Colleges and the present English teaching status. Lastly, several optimization methods are put forward.
\end{abstract}

\section{Introduction}

English teaching in Higher Vocational Colleges has won more and more attention, but at the same time, because of the "Internet+", it has confronted with great changes and higher requirements. However, in the present English teaching in Higher Vocational Colleges, it is very common to see problems like outmoded teaching modes, inefficient teaching, poor English learning atmosphere, application incompetence of students, etc. The English teaching status fails to meet Higher Vocational talent needs of our society. Therefore, it is of great practical importance to explore the optimization of Higher Vocational English teaching under the "Internet+" environment.

\section{The Influence of "Internet+" on Higher Vocational English Teaching}

The "Internet+" has an important influence on the Higher Vocational teaching ideas. In the traditional teaching modes, teachers teach and students just listen. This kind of indoctrination mode can not arouse students' learning initiative and fails to obtain good teaching effects. Under the "Internet+" environment, teaching modes and contents have undergone great changes. The Internet makes teaching contents more intuitive and vivid and teaching modes more flexible. The autonomous and open learning mode has also varied the traditional teaching and learning methods, promoted the transformation of teachers' role in classroom as well as made it more conducive to cultivate students' comprehensive ability and quality. Specifically, through Internet platforms, teachers and students will be able to achieve interactive communication which can facilitate the individualized education. In the traditional English classes, students are always not willing to speak and afraid of losing faces due to mistakes. The teachers also give insufficient chances for students to practice. This kind of “dumb” English makes English teaching quite difficult. Based on Internet, students are able to exchange views more boldly in the virtual platforms and classes. Learning atmosphere will undoubtedly be more free and students' initiative and interests will be naturally activated. Meanwhile, the "Internet+" has also brought tremendous impacts on Higher Vocational students' learning. With the rapid development of mobile Internet and the popularity of smart mobile equipments, students can make full use of Internet to achieve more knowledge by themselves. So, it is feasible to reconstruct classes through Internet technology platforms, provide more curriculum resources to students and form open, interactive and rich-media English teaching classes. In order to integrate students' English learning modes and needs of their future work and life, teachers must apply modern teaching technologies to classes. In addition, Internet offers tremendous convenience to people's lives. For example, it makes the communication among people 
easier and more convenient, getting rid of the limitation of time and space. By applying this advantage of Internet to Higher Vocational English teaching, it will enhance effectively the interaction between teachers and students as well as students between students which will further promote their communication skills. Teachers also can master students' learning conditions and adjust teaching contents according to actual situations. ${ }^{[1]}$

Meanwhile, under the "Internet + " environment, new English teaching modes in Higher Vocational Colleges put forward higher requirements for teachers. English teachers are supposed to bear noble ideological quality and spiritual realm, possess extensive and profound professional knowledge and educational theories, have strong ability to do educational and scientific researches and innovate knowledge, as well as be proficient to master and apply modern teaching technologies. With further development and perfection of Higher Vocational education, the comprehensive quality of their students has been gradually attached by more attention from our society. The contents and modes of curricula in Higher Vocational Colleges should be more relevant to students' future career life and adapt to the needs of social development. Therefore, under the "Internet+" environment, Higher Vocational Colleges need to construct new English teaching modes conforming to the characteristics of professional education by taking colleges' factual situations into full consideration.

\section{The Analysis of Present Higher Vocational English Teaching Status}

In recent years, working as an important transmission carrier of information resources, the Internet has been widely applied in educational practice. The traditional classroom teaching mode has gradually extended to the Internet teaching mode and undergone transformational development. Numerous network courses teaching modes appear, providing more convenient leaning channels to students. However, the current English teaching ideas and objectives of many Higher Vocational Colleges are still outmoded. They still take the teacher-centered teaching mode, lacking sufficient understanding of the importance to integrate Internet into teaching and their application of Internet to teaching practice is limited. Moreover, the teaching objectives are also not clear. Neither the teachers nor students know whether the English knowledge which is taught or learned satisfies the major needs or the market demands, let alone to what extent the English knowledge level should reach. These problems have greatly affected English teachers' teaching enthusiasm and students' learning initiative.

After College Entrance Examinations, many Higher Vocational students feel frustrated, lacking learning initiative. From the English teaching practice, it is easy to find that some students are inactive, unconfident and have poor self-control ability. They possess very limited English vocabulary as well as insufficient oral communication ability. While, in our teaching, a lot of teachers still take the traditional "indoctrination" teaching mode in which students' subjectivity status is vacant and they can achieve few chances to practice, resulting into their general interests losing and phone usage in the classes. Especially under the Internet environment, with the continuous development of Internet technologies, various network teaching modes like micro class, MOOC and so on gradually appear. In such an Internet environment, English teaching becomes more abundant and vivid. However, the current Higher Vocational English teaching has not made full use of Internet information technology platforms. ${ }^{[2]}$

The current English teaching contents of some Higher Vocational Colleges are comparatively easy. Most teachers explain word by word and sentence by sentence. Meanwhile, the English teaching materials are obsolete whose contents are invariant without sense of freshness and reality, not closely related to students' learning, living and future career, and fail to arouse their learning interests. Students and teachers generally pay great importance to public English tests which is regarded as a necessary measurement of students' graduation standard. Therefore, many students spend substantial time on preparation, or even sign up for professional tutoring classes in order to obtain the certificates. As a result, students' English practical application ability is neglected to a certain extent. They tend to be good at examinations, but are poor in English communicative competence. 
With the continuous development of Higher Vocational education, our society puts forward higher requirements for its talents cultivating modes and also brings more challenges to English teachers. In view of the current situation, there is a shortage of English teachers and ratio imbalance between teachers and students. In addition, although "Internet+" has brought great changes to teaching modes, the application of Internet to teaching is still inadequate. Apart from the mostly used PPT, there is no substantive change in the teaching modes. Most teachers are not proficient in Internet skills. For example, some teachers have not mastered the skills to do video recording and editing of micro classes, which fails to meet the teaching needs in "Internet+" age. Besides, because of various subjective and objective factors, teachers lack enough training and learning opportunities.

\section{The Optimization Methods of Higher Vocational English Teaching under the "Internet+" Environment}

Under the "Internet+" environment, it is necessary for Higher Vocational English teachers, especially these practical teachers, to reconsider and plan their own teaching. They are supposed to change teaching ideas properly, accommodate to the new development, produce new English teaching ideas and combine English teaching spirits with "Internet+". The educational teaching ideas are the foundation of teaching activities. For Higher Vocational English teachers, only cultivating brand new ideas will play a positive and instructional role in educational teaching work and be helpful to put forward more active information processing methods. The Higher Vocational English teaching must target students' application, helping students to achieve the latest knowledge before their working and apply these knowledge into practice. Hence, English teachers in Higher Vocational Colleges should accommodate to the development of the age, accept all kinds of Internet knowledge, learn to use Internet platforms, apply actively various Internet teaching methods, enrich teaching contents, improve teaching efficiency and meet students' learning and development needs.

Under the "Internet+" environment, teachers' role of explaining knowledge points in classroom is losing importance. Hence, they need to actively use the project teaching method, MOOC, Flipped Classroom and so on to adapt to the classroom teaching modes required by "Internet+". Teachers are supposed to pay attention to instruct students to actively change learning methods and learn to explore as well as think independently. The individual differences of students should be respected. It is required to emphasize students' personality learning, utilize multiple evaluation methods and cultivate students' teamwork which meets the cooperation spirits requirements of "Internet+". For instance, in English translation teaching, it is feasible for teachers to release background knowledge graphically on the Internet sharing platforms like WeChat Public Number, Micro-blog account and so on to guide students to learn and read. Meanwhile, a passage with moderate difficulty can be attached to the background knowledge whose contents are closely related to the texts which is to be explained in classes. ${ }^{[3]}$ Students are required to form several groups autonomously, finish discussion and translation before class, as well as share their thoughts and questions on the Internet with other students and teachers. In the class, each group presents their own translations in front of all classmates, narrates the details during the process of translation including translation thoughts, skills, difficulties and solutions. After all groups finish, all students offer evaluation to each other. Lastly, the teacher summarizes problems which are confronted in translation and explains important points.

On the one hand, teachers need to actively enrich listening and speaking contents in students' daily English learning by using Internet. With multimedia technologies and other teaching techniques, teachers are able to introduce real English situations which may be involved in workplace into classes. Thus, students' learning interests will be enhanced and English application ability will be promoted. For example, it is suggested to turn English teaching contents into micro videos then upload them to Internet sharing space. Students can pick a topic and make a small English video. The participation will be a part of their final assessment which will improve learning effects. On the other hand, in listening, speaking, reading and writing teaching, teachers will be able to apply real reading and writing materials to Internet learning by making use of Internet big data and provide more communicative chances to help students master English better. In addition, with 
the popularity of smart mobile terminals, more and more students are used to learning on APP. English teachers in Higher Vocational Colleges also can do researches to design interesting English learning APP softwares according to their students' level. This software can set a variety of modules, such as words learning, daily English, consulting solutions, chat rooms, small English tests and so on. Those rich contents will not only promote communications between teachers and students, and enhance English learning interests, but also fuse teaching with examination system, improve students' learning quality and promote their English practical ability.

Under the "Internet+" environment, it is quite vital to strengthen the construction of English teaching faculty. Specifically speaking, first of all, we should enhance the training of in-service teachers, urge their self-improvement, guide them to learn to communicate with worldwide colleagues on the Internet as soon as possible, get to know the development trend of English teaching, accept new teaching thoughts and share new English teaching resources. With these resources, teachers are able to enrich teaching contents and methods, construct a brand new teaching environment and enhance students' learning initiative, all of which will be apt to help teachers realize the purpose of promoting themselves and improving teaching effects. Secondly, English teaching is a dynamic activity. In English teaching reform, new problems may occur at any time. Therefore, colleges should possess academic leaders, introduce talents or tap internal talents. Higher Vocational Colleges are supposed to boldly cultivate and use young people who are diligent and dedicated, proficient in their profession, pioneering and keeping pace with the times. Thus, in the personnel aspect, they not only can achieve "make the best of everything", but also find, study and solve problems at any time, guaranteeing a smooth, continuous and effective English teaching reform on the right track.

\section{Conclusion}

In a word, under the "Internet+" environment, Higher Vocational English teaching is confronted with new development and challenges. We must positively take advantage of Internet, update teaching ideas and teaching technologies, innovate teaching methods, perfect teaching modes, stimulate students' English learning autonomy and then comprehensively improve English teaching quality as well as effects.

\section{Acknowledgements}

The work was supported by the first national higher vocational foreign languageteaching reform research project with the project number GZWYJXGG-080 and the project name Empirical Researc $\mathrm{h}$ on the English Learning Effectiveness Based on Blending Teaching.

\section{References}

[1]Zhang Lei. An Exploration on the English Teaching Modes Reform of Higher Vocational Colleges under the Internet Environment [J]. C Crazy English, Teacher Edition, 2015 (2): 130-132.

[2]Xu Yi, Tian Chunyan. A Study and Implementation of Mobile English Learning Platforms Based on Android [J]. The Chinese Journal of ICT in Education, 2014 (4): 87-90.

[3]Xie Yudan. A Study of Higher Vocational English Teaching Modes Based on "Internet+" [J]. English on Campus · first volume, 2015 ( 8): 82-83. 